\title{
Medical Causes of Death among the Elderly in a Tertiary Hospital in South East Nigeria
}

EB Arodiwe, SC Nwokediuko, SO Ike, II Ulasi, CK Ijoma

\begin{abstract}
Background: There are few data on morbidity and mortality patterns among the elderly in Africa, especially in Sub-Saharan Africa (SSA). The aim of this study was to determine the causes of death among the elderly population in the internal medicine wards of a tertiary health institution in South East Nigeria.

Methods: This was a retrospective study conducted on patients 60 years and older, who died in the medical wards of the University of Nigeria Teaching Hospital between January 1995 and January 2010. Relevant information was obtained from their case notes and death certificates.

Results: Six thousand, two hundred and fifty patients died during the period of this study. Out of this, 1941 were aged $\geq 60$ years, giving a death rate of $31.1 \%$; $63.1 \%$ were males, $36.9 \%$ were females. The mean age at death for the males was $69.9 \pm 7.9$ years and for the females $69.1 \pm 7.5$ years $(\mathrm{p}<0.033)$. The overall mean age at death was $69.6 \pm 7.7$ (range 60-102) years. The most common diagnosis at death among the men was stroke (11\%), chronic kidney disease (5.7\%) and diabetic complications (5.5\%). Among the women, it was stroke (8.4\%), heart failure (3\%) and chronic kidney disease (2.5\%).

Conclusion: The three most common causes of death among males and females were chronic non-communicable diseases. The importance of the prevention, early diagnosis and appropriate treatment of the underlying diseases and their complicaitons cannot be overemphasized.
\end{abstract}

Keywords: Death, elderly, medical causes, South East Nigeria

\section{Causas Médicas de Muerte entre los Ancianos de un Hospital Terciario en Nigeria Suroriental}

EB Arodiwe, SC Nwokediuko, SO Ike, II Ulasi, CK Ijoma

\begin{abstract}
RESUMEN
Antecedentes: Hay pocos datos sobre la morbilidad y los patrones de mortalidad entre los ancianos en África, especialmente en el África Subsahariana (ASS). El objetivo de este estudio fue determinar las causas de muerte entre la población anciana en las salas de medicina interna de una institución terciaria de la salud en Nigeria Suroriental.

Métodos: Se trató de un estudio retrospectivo realizado en pacientes de 60 años o más de edad, que murieron en las salas médicas del Hospital Docente Universitario de Nigeria entre enero de 1995 y enero de 2010. Se obtuvo información relevante de sus historias clínicas y certificados de defunción.

Resultados: Seis mil doscientos cincuenta pacientes murieron durante el periodo de este estudio. De estos, 1941 fueron de edad $\geq 60$ años, para una tasa de mortalidad de 31.1\%. El 63.1\% eran varones, y el $36.9 \%$ eran mujeres. La edad media de muerte para los varones fue de $69.9 \pm 7.9$ años y para las hembras $69.1 \pm 7.5$ años $(p<0.033)$. La edad media general de muerte fue de $69.6 \pm 7.7$ años (rango 60 102). Los diagnósticos más comunes de muerte entre los hombres fueron el accidente cere-brovascular (11\%), la enfermedad renal crónica (5.7\%) y las complicaciones diabéticas (5.5\%). Entre las mujeres, fueron el accidente cerebrovascular (8.4\%), la insuficiencia cardíaca (3\%), y la enfermedad renal crónica $(2.5 \%)$.
\end{abstract}

From: Department of Medicine, University of Nigeria Teaching Hospital, Ituku/Ozalla, Enugu, Nigeria.
Correspondence: Dr EB Arodiwe, Department of Medicine, University of Nigeria Teaching Hospital, Ituku/Ozalla, Enugu, Nigeria. Email: arodiwenephrol@yahoo.com 
Conclusión: Las tres causas de muerte más comunes entre varones y hembras fueron las enfermedades crónicas no transmisibles. Resulta poco todo cuanto se pueda decir para enfatizar la importancia de la prevención, diagnóstico precoz y tratamiento apropiado de las enfermedades subyacentes y sus complicaciones.

Palabras claves: muerte, ancianos, causas médicas, Nigeria Suroriental

West Indian Med J 2017; 66 (1): 51

\section{INTRODUCTION}

Ageing is often associated with increasing disease and disability, especially chronic diseases. This is supported by morbidity and cause of death statistics (1). For example, ageing is the most powerful risk factor for cardiovascular disease (2). The observed trend in developed countries is that the elderly population is on the increase. Demographers, however, predict that by the year $2020,70 \%$ of the world's elderly population will be found in developing countries (3). The costs associated with this increase in older adults are going to be enormous and have huge implications for both the developed and developing countries. But, the impact may be felt more in the developing countries that overall have fewer resources to deal with an ageing situation (4).

In the past four decades, Africa has witnessed increasing urbanization and changing lifestyles. These are factors which have in turn raised the incidence of non-communicable chronic diseases, especially cardiovascular diseases. At the same time, social disintegration and inequality, compounded by dwindling economies in many countries in Sub-Saharan Africa (SSA) have seriously hindered the response to these diseases (5). Infectious diseases - especially HIV/AIDS and tuberculosis - are also common.

In SSA, non-communicable diseases are the most common causes of death in patients aged 60 years and above (6). Ischaemic heart disease (IHD) was the most common cause of death in elderly men accounting for about $13.4 \%$ of deaths while cerebrovascular accident (CVA) was the most common in elderly women accounting for $17 \%$ of deaths (6). However, infectious diseases are also common causes of death in this age group in SSA. Lower respiratory tract infections were the third most common causes of death in both genders, accounting for $6.5 \%$ of deaths in males and $5.6 \%$ in females (6).

Elderly patients constitute a high proportion of in-patient medical admissions in Nigeria. They account for $41 \%$ of the admissions to the medical wards (7). Mortality among this group is also high accounting for $26.7 \%$ and $22.8 \%$ of deaths, respectively, in two separate studies from the south and middle belt regions of Nigeria $(7,8)$. Stroke, $19.8 \%$, sepsis, $16.5 \%$ and lower respiratory tract diseases $8.1 \%$, were the three most common diagnoses at death (8). Infectious diseases accounted for $38.2 \%$ of all the diagnoses (8).

There are very few studies generally on mortality and morbidity patterns among the elderly in Nigeria and most SSA countries. In this region, where this study was conducted, geriatric services are non-existent. In Nigeria, the percentage of the population over 60 years of age was put at $5.13 \%$ in the 1991 census (9). There is no national policy on the welfare or social security packages for the senior citizens in Nigeria and most countries in SSA. There are also no geriatric hospitals in the country.

This paper therefore examines in-hospital mortality among the elderly patients admitted to the internal medicine wards at a tertiary institution in order to determine the patterns and causes of death and help draw the attention of policy-makers to the elderly and their health problems.

\section{SUBJECTS AND METHODS}

This was a retrospective cross-sectional study conducted from January 1995 to January 2010 on patients aged 60 years and above who died in the adult medical wards of the University of Nigeria Teaching Hospital (UNTH), Enugu. The University of Nigeria teaching hospital is a tertiary health institution strategically located in the South East zone of Nigeria. This hospital is located among the Ibo-speaking ethnic group of Nigeria. It serves approximately a quarter to a third of the Nigerian population which is currently estimated to be 158.2 million (10). The hospital receives patients from Enugu State (where it is located), and from neighboring states of Kogi, Anambra, Ebonyi, Abia and Imo. Enugu State covers an estimated area of $7161 \mathrm{~km} \mathrm{(10).}$

The internal medicine wards (where this study was conducted) has 120 beds. All the patients admitted to the internal medicine wards of the UNTH during the study period - whose case notes and death certificates were available in the archives of the hospital registration room - were included. The case notes were classified according to the year of admission. All the cases found during the study period were included. The dependent variables in this study were: the reasons for admission and causes of death, while the explanatory variables included the sociodemographic characteristics of the patients in the case notes reviewed. Autopsy was not done on any of the patients.

During the data collection, two interns reviewed the case notes of the patients admitted to the medical wards, the ward registration books and the death certificates. The data collectors were trained on how to complete the structured data collection format prepared for the study. The causes of death were documented from the registration book and death the certificates and then sorted using the International Classification of Diseases (ICD) version ten, 2007 (11). The data obtained were entered into SPSS version 17.0 and analysed. $\mathrm{X}^{2}$ tests of asso- 
ciation were done wherever appropriate, $p$-values $<0.05$ were taken to be statistically significant. Ethical clearance was obtained from the hospital ethics committee. The confidentiality of personal information was maintained during the data collection, analyses and interpretations. The following operational definitions were used in the study:

- Diseases causing death are the primary diagnoses given as the causes of death.

- Systemic cause of death is the system to which the primary disease belongs.

\section{RESULTS}

A total of 6250 patients died in the medical wards during this period. Of these, 1941 were aged 60 years and above giving a crude mortality rate of $31.1 \%$. Among these elderly population, $1225(63.1 \%)$ were men. The male to female ratio was 1.7 to 1 . The age of the patients ranged from 60 to 102 years. The mean age of the patients was $69.6 \pm 7.7$ years. The mean age at death for the females was significantly lower than that for the males, $69.1 \pm 7.5$ years, as against $69.9 \pm 7.9$ years $(p$ $=0.033)$. The highest number of deaths, 563 (29\%), occurred in the age group 60 to 64 years (Table 1).

Table 1: Sociodemographic characteristics of the patients

\begin{tabular}{lccr}
\hline \multicolumn{2}{l}{ Sociodemographic variables } & $(\mathbf{n}=\mathbf{1 9 4 1})$ & \\
Gender & $\mathbf{n}(\%)$ & Mean age in years (SD) & $\boldsymbol{p}$ \\
\hline Male & $1225(63.1)$ & $69.9(7.9)$ & 0.033 \\
Female & $716(36.9)$ & $69.1(7.5)$ & \\
Total & $1941(100)$ & $69.6(7.7)$ & \\
Age range (years) & Male, $\mathrm{n}(\%)$ & Female, $\mathrm{n}(\%)$ & Total, $\mathrm{n}(\%)$ \\
60-64 & $339(17.5)$ & $224(11.5)$ & $563(29.0)$ \\
$65-69$ & $268(13.8)$ & $155(8.0)$ & $423(21.8)$ \\
$70-74$ & $302(15.6)$ & $149(7.7)$ & $451(23.3)$ \\
$75-79$ & $147(7.6)$ & $111(5.7)$ & $258(13.3)$ \\
$\geq 80$ & $169(8.7)$ & $77(4.0)$ & $246(12.7)$ \\
\hline Total & $\mathbf{1 2 2 5 ( 6 3 . 1 )}$ & $\mathbf{7 1 6 ( 3 6 . 9 )}$ & $\mathbf{1 9 4 1 ( 1 0 0 )}$ \\
\hline
\end{tabular}

$\mathrm{X}^{2} 12.436$, df $5, p<0.029$
The most common systemic causes of death among these patients were the diseases of the circulatory system, 650 (33.4\%). This was followed by miscellaneous conditions (ie those with non-specific diagnoses and few spondylopathies and other musculoskeletal disorders, 249 (12.9\%). Infections and parasitic diseases, 203 (10.4\%), diseases of the genitourinary system, 191 (9.8\%), diseases of the digestive system, 162 $(8.4 \%)$ and, diseases of endocrine/nutritional and metabolic system, 155 [8\%] (Table2).

Overall, there was a significant association between the gender of the patients and the causes of death according to the various systems $\left(\mathrm{x}^{2}=27.943, p<0.002\right)$. The most common clinical condition causing death in both genders was cerebrovascular accident (CVA), accounting for 377 (19.4\%) of all the deaths. This was followed by chronic kidney disease (CKD), 160 (8.2\%) and cardiac failure; especially from hypertensive heart disease, 155 (7.9\%). Others were: diabetes mellitus and its complications 150 (7.7\%), septicaemia 130 (6.7\%), chronic liver disease $113(5.8 \%)$ and the pneumonias $58(3 \%)$. Among the men, the three most common causes of death were CVA, 214 (11\%), CKD, 111 (5.7\%) and diabetes mellitus and its complications, $108(5.5 \%)$. In the females, CVA, 163 (8.4\%), cardiac failure, 59 (3\%) and CKD $49(2.5 \%)$ were the most common (Table 3 ).

\section{DISCUSSION}

This is a retrospective cross-sectional study spanning a period of 16 years (January 1995 to January 2010). The results showed a crude mortality rate of $31.1 \%$. This is high compared with a similar study in the middle belt of Nigeria, which showed a crude mortality rate of $22.8 \%$ (8). Mortality from other parts of the world in a similar age group ranged from $16.4 \%$ to $20 \%(12-14)$. The wide variations in the mortality rates among the different studies can be attributed to several factors ranging from: the degree of hospital specialization, patients' characteristics, financial constraints, late presentation (most patients having gone to prayer houses and traditional

Table 2: Association of the gender of the patients with systemic causes of death

\begin{tabular}{|c|c|c|c|c|}
\hline \multirow{2}{*}{\multicolumn{2}{|c|}{ ICD Category Systemic causes of death }} & \multicolumn{2}{|c|}{ *Gender } & \multirow[b]{2}{*}{ Total } \\
\hline & & Male & Female & \\
\hline A or B & Infections/parasitic disease & $139(7.2)$ & $64(3.3)$ & $203(10.5)$ \\
\hline $\mathrm{C}$ & Malignant neoplasm & $58(3.0)$ & $32(1.6)$ & $90(4.6)$ \\
\hline $\mathrm{D}$ & Anaemia/haematological & $19(1.0)$ & $13(0.7)$ & $32(1.7)$ \\
\hline $\mathrm{E}$ & Endocrine/nutritional and metabolic & $113(5.8)$ & $42(2.2)$ & $155(8.0)$ \\
\hline G & Disease of the nervous system & $50(2.6)$ & $32(1.6)$ & $82(4.2)$ \\
\hline I & Disease of the circulatory system & $381(19.6)$ & $269(13.8)$ & $650(33.4)$ \\
\hline $\mathrm{J}$ & Disease of the respiratory system & $72(3.7)$ & $55(2.8)$ & $127(6.5)$ \\
\hline K & Disease of the digestive system & $112(5.8)$ & $50(2.6)$ & $162(8.4)$ \\
\hline $\mathrm{M} / \mathrm{O}$ & $\begin{array}{l}\text { Spondylopathies and other musculoskeletal } \\
\text { system/miscellaneous conditions }\end{array}$ & $145(7.5)$ & $104(5.4)$ & $249(12.9)$ \\
\hline $\mathrm{N}$ & Diseases of the genitourinary system & $136(7.0)$ & $55(2.8)$ & $191(9.8)$ \\
\hline \multicolumn{2}{|l|}{ \#Total } & $1225(63.2)$ & $716(36.8)$ & $1941(100)$ \\
\hline
\end{tabular}

*Number (\%), $\mathrm{X}^{2}=27.943, \mathrm{df}=10, p<0.002$ 
Table 3: Common specific diseases causing death among the elderly

\begin{tabular}{lcrr}
\hline Disease & n (\%) & Male, n (\%) & Female, n (\%) \\
\hline Cerebrovascular accident & $377(19.4)$ & $214(11)$ & $163(8.4)$ \\
Chronic kidney disease & $160(8.2)$ & $111(5.7)$ & $49(2.5)$ \\
Cardiac failure & $155(7.9)$ & $96(4.9)$ & $59(3.0)$ \\
Diabetes mellitus/complications & $150(7.7)$ & $108(5.5)$ & $42(2.2)$ \\
Septicaemia & $130(6.7)$ & $88(4.5)$ & $42(2.2)$ \\
Chronic liver disease & $113(5.8)$ & $81(4.2)$ & $32(1.6)$ \\
Pneumonias & $58(3.0)$ & $37(1.9)$ & $21(1.1)$ \\
Meningoencephalitis & $37(1.9)$ & $19(1.0)$ & $18(0.9)$ \\
Anaemia & $29(1.5)$ & $18(0.9)$ & $11(0.6)$ \\
Tuberculosis & $27(1.4)$ & $26(1.3)$ & $1(0.1)$ \\
Hepatoma & $27(1.4)$ & $16(0.8)$ & $11(0.6)$ \\
Acute kidney injury & $23(1.2)$ & $18(0.9)$ & $5(0.3)$ \\
Cardiopulmonary failure & $267(13.7)$ & $188(9.4)$ & $79(4.1)$ \\
\hline
\end{tabular}

$\mathrm{n}=$ Number of cases

A non-specific condition generally termed respiratory failure/cardiorespiratory failure with some musculoskeletal conditions accounted for $13.7 \%$ of the deaths: $9.4 \%$ in the men and $4.1 \%$ in the women.

medical healers prior to their admission), and the severity of their illness at the time of their presentation (15-17). Other contributing factors are: poor emergency response, the unavailability of the facilities crucial to the examination and management of very ill patients and unavailability of very important medications. There exist - in many developing nations - a very poor or no social service to care for the older citizens. As a result, they are solely dependent on their children and relatives for their upkeep and the settlement of their healthcare bills $(8,18)$.

The patients' mean age at death in this study was $69.6 \pm$ 7.7 years. This is lower than that from the developed nations $(12,13,15,19)$. The higher mean age at death in the elderly populations of the industrialized nations compared to ours is due to a higher standard of living, better healthcare facilities, population health-seeking behaviour and a general higher life expectancy. The males' deaths constituted $63.1 \%$ of the mortality in our study. The mean age at death in the males (69.9 \pm 7.9 years) was higher than in the females $(69.1 \pm 7.5$ years $)$, $p<0.033$. This difference is difficult to explain, as there are conflicting reports from some studies that reported equal mean age (20). Generally, in this study, there is evidence to suggest that hospital deaths were more in the older males than females and, earlier observations had shown that females tend to live longer than males $(21,22)$. Nevertheless, at older age, females reported greater numbers of morbidity and disability and the use of healthcare facilities when compared to males (22).

The diseases of the circulatory system (33.4\%) were the most common causes of the deaths in our study. These were followed by infectious and parasitic diseases $(10.4 \%)$ and the diseases of the genitourinary system $(9.8 \%)$. This pattern was maintained in both genders except that in the females, the diseases of the genitourinary and respiratory systems were each responsible for $2.8 \%$ of the deaths and were the third most common causes of the deaths. Cerebrovascular accident (circulatory system) was the commonest disease causing death overall $(19.4 \%)-11 \%$ in men and $8.4 \%$ in women. This is similar to the findings from Ilorin, South West Nigeria, in which the same system accounted for almost a-quarter of the deaths with strokes being the most common diagnosis at death. The second and third most common diseases in the same study were sepsis/infection and lower respiratory diseases, respectively (8).

The observations of these studies are in line with those of some previous studies, which showed that stroke is becoming the greatest killer disease in Africa and often affects all the age groups $(23,24)$. In South Africa, cardiovascular diseases were the primary causes of death accounting for $43 \%$ of the deaths in people 60 years and above. Ischaemic heart disease and stroke were the two leading causes of death in the South African study, with the order reversed for men and women (25). In the industrially advanced countries of Europe and North America, the three leading causes of deaths in people 65 years and above were: heart diseases, malignant neoplasm and cerebrovascular accidents $(23,26)$.

The changes in peoples' lifestyles and dietary habits are two distinct features that have been particularly reported to account for the increase in the number of cardiovascular disorders being experienced in most developing countries $(25,29)$. The finding of $19.4 \%$ stroke mortality in the present study is most likely the tip of the iceberg, as several cases of stroke in Africa rarely get to the hospitals before the patients' deaths (23). The explanations for these cases include: the poor transportation systems, limited access to healthcare and neurodiagnostic facilities, deficient acute interventional therapy, the dearth of medical experts, the poor medical interpretations of the symptoms of stroke in the communities and, the continued use of traditional and alternative healers (23). It is important to note that hypertension and diabetes mellitus or the combinations of both in an individual are the most common aetiologic agents of stroke in SSA. This underlines the importance of these two non-communicable diseases as the causes of high morbidity and mortality in Africa $(28,29)$.

In the present studies, infectious diseases, mostly septicaemia, were the second most common systemic causes of the deaths. This finding is similar to what has been documented by other hospital-based studies in Nigeria $(8,16,17,24,30,31)$. The reasons proposed for this pattern in SSA include: the alterations in the structure and functions of the respiratory tract with ageing making them susceptible to infection, the fall in the immunity level associated with ageing, poverty, high level of illiteracy, the abuse of antibiotics and poor sanitation $(16,30$, 32 ). When the elderly fall sick, they often become extremely weak and bed-bound. This can lead to decubitus ulcers. If they stop eating or drinking, dehydration may set in, thereby necessitating the insertion of intravenous lines, urinary catheters, and nasogastric tubes for feeding, all of which increase the risk of infection (16). The ageing of the immune system and the reduced level of personal hygiene from frailty also make older people vulnerable to sepsis and infection (16). It was therefore not surprising that those infectious diseases, which are 
preventable, accounted for $10.4 \%$ of the mortality documented in this study.

Worthy of note is the impact of chronic kidney disease as an important cause of death among the elderly population in this study, accounting for $8.2 \%$ of all the deaths. It was the second most common disease causing death in the males $5.7 \%$ of all the deaths) and the third in the females $(2.5 \%$ of all the deaths). Chronic glomerulonephritis, hypertension, and diabetes mellitus are the most common causes of chronic kidney disease in SSA and in Africa as a whole (33-38). This underscores the increasing burden of communicable diseases, on the existing background of predominant infectious disease, as important causes of morbidity and mortality of the elderly in SSA.

Other important causes of the deaths in this study were: cardiac failure accounting for $7.9 \%$ of the deaths $(4.9 \%$ in the males and $3 \%$ in the females), diabetes mellitus and its complications accounting for $7.7 \%$ of the deaths $(5.5 \%$ in the males and $2.2 \%$ in the females) and chronic liver disease accounting for $5.8 \%$ of the deaths $(4.2 \%$ in the males and $1.6 \%$ in the females). Overall, congestive cardiac failure was the third most common conditions causing death among this elderly population. Hypertensive heart disease, cardiomyopathies and various valvular diseases are the most common causes of heart failure in SSA and the major contributors to the deaths of our patients $(39,40)$.

The prevalence of diabetes mellitus in SSA is rising rapidly especially with the increasing age and the westernized lifestyles of the people. This prevalence is estimated to rise by $80 \%$ in 20 years' time (41). Most of the diabetic patients died from septicaemia, mostly from diabetic foot ulcer, hyperglycaemic hyperosmolar coma, diabetic ketoacidosis and cerebrovascular accident $(29,42)$. Chronic hepatitis $\mathrm{B}$ and $\mathrm{C}$ virus infection and chronic alcohol ingestion are the leading causes of chronic liver disease in our environment with most of the patients dying from the complications of hepatic encephalopathy, bleeding oesophageal varicies, sepsis and the complications of associated primary liver cell carcinoma $(43,44)$.

Other contributing causes of death include: meningoencephalitis $(1.9 \%)$, anaemia from various causes $(1.5 \%)$, hepatoma (1.4\%), tuberculosis (1.4\%) and acute kidney injury $(1.2 \%)$. It is important to mention that the contribution of tuberculosis (TB) could be underestimated in this study as those with open TB were usually admitted on the chest ward, which is under another department (community medicine). It is also important to note the relatively low prevalence of HIV-infection $(0.8 \%)$, leukaemia $(0.8 \%)$, and carcinoma of the prostate $(0.6 \%)$ as the causes of deaths in this sample of patients. These diseases are important causes of death among the young and middle-aged in SSA $(45,46)$. A relatively large number of the patients in this study $(13.7 \%$, Table 3$)$ were documented to have died from cardiorespiratory failure of unspecified causes. This underlines the importance of educating doctors in SSA regarding the standard documentation of the causes of death especially in an environment where autopsy is infrequent because of sociocultural factors.

\section{CONCLUSION}

The mortality amongst the elderly patients admitted to the hospital in this study is high. Non-communicable diseases were the most common diagnoses at their deaths. The impact of communicable diseases (infections/parasitic diseases) as systemic causes of death was also strong emphasizing the dual burden of communicable and non-communicable diseases in SSA. There might be the need for healthcare givers to pay more attention to the older patients with the signs and symptoms suggestive of stroke, chronic kidney disease, diabetes mellitus and sepsis.

More efforts are needed to decrease the growing number of cardiovascular risk factors being experienced in many developing countries because of the influence of western culture.

One limitation of this study is its hospital-based nature. There were also no postmortem reports to corroborate the clinical diagnoses. However, hospital-based reports, have their usefulness especially, in our setting, where effective national basic data collation tools are not easily available. Communitybased studies on the patterns of morbidity and mortality among the aged are needed to look at the relevance of our finding within the context of a larger community. Continuing medical education would help in training healthcare personnel, particularly doctors on the appropriate documentation of both the primary, secondary and other associated causes of deaths in the elderly.

\section{AUTHORS' NOTE}

The authors declare no conflict of interest.

\section{REFERENCES}

1. Joubert JD, Bradshaw D. Population ageing and its health challenges in South Africa. Mac technical report; 2006.

2. Mbewu AD. "Can developing country systems cope with the epidemics of cardiovascular disease?" Paper presented at the Heart health conference, New Delhi, India, 1998.

3. Kalache A. Active ageing makes the difference: Editorial, bulletin of the World Health Organization 1999; 77: 299.

4. Zuehkle E. Gender differences in health among the elderly in China Population reference Bureau, June 2009. www.pob.org/publication/Article/2009/chinaelderlyheath.aspx.

5. Duchateau FX, Ricard-Hibon A, Devand ML, Burnod A, Mantz J. Does ageing influence quality of care for acute myocardiac infarction in the pre-hospital setting? Elderly patients with acute myocardiac infarction. Am J Emerg Med 2006; 24: 512.

6. Jamison DT, Feachem RG, Makgoba MW, Bos ER, Baingana FK, Hofman KJ et al. The International Bank for Reconstruction and Development / The World Bank; 2006.

7. Onwuchekwa AC, Asekomeh G. Geriatric Admissions in a developing country: Experience from a tertiary centre in Nigeria. Ethn Dis 2009; 19: 359-62.

8. Sanya EO, Akande TM, Opadijo G, Olarinoye JK, Bojuwoye BJ. Pattern and outcome of medical admission of elderly patients seen in University of Ilorin teaching hospital Ilorin. Afr J Med Sci 2008; 37: 375-81. 
9. Nigerian population. http://www.tradingeconomics.com/nige-ria/ population.

10. [Internet] Nigeria Population Commission. http://www.population. Gov.ng.

11. Central Statistical Services. International statistical classification of diseases and related health problems, ICD $10^{\text {th }}$ revision, 2007; Jan: 1-62.

12. Lamont CT, Sampson S, Matthias R, Kane R. The outcome of mortality of hospitalization for acute illness in the elderly. J Am Geriatr Soc 1983; 31: $282-8$.

13. Silva TJ, Jerussalmy CS, Farfel MJ, Curiati JA, Jacob-Filho W. Predictors of in-hospital mortality among older patients. Clinics (Sao Paulo) 2009; 64: 613-8.

14. Shoko T, Shiraishi A, Kaji M, Otomo Y. Effects of pre-existing medical conditions on in-hospital mortality: Analysis of 20,257 trauma patients in Japan. J Am Coll Surg 2010; 211: 338-46.

15. Alarcon T, Barcena A, Gonzalez-Montalvo JI, Penalosa C, Salgado A Factors predictive of outcome on admission to an acute geriatric ward. Age Ageing 1999; 28: 429-32.

16. Sanya EO, Abiodun AA, Kolo P, Olanrewaju TO, Adekeye K. Profile and causes of mortality among elderly patients seen in a tertiary care hospital in Nigeria. Ann Afr Med 2011; 10: 278-83.

17. Ogun SA, Adelowo OO, Familoni OB, Jaiyesimi AE, Fakoya EA. Pattern and outcome of medical admissions at the Ogun state university teaching hospital, Sagamu - A three-year review. West Afr J Med 2000; 19: $304-8$

18. Akanji BO, Ogunniyi A, Bayewu O. Healthcare for elderly persons, a country profile: Nigeria. J Am Geriatr Soc 2002; 50: 1289-92.

19. Incalzi RA, Gemma A, Capparella O, Terranova L, Porcedda P, Tresalti E et al. Predicting mortality and length of stay of geriatric patients in an acute care general hospital. J Gerontol 1992; 47: 35-9.

20. Kolo P, Chijioke A. Gender disparities in mortality among medical admissions of a tertiary health facility in Ilorin, Nigeria. Internet J Tropical Med 2009; 6: 1 .

21. Macantyre S, Hunt K, Sweeting H. Gender differences in health: Are things really as simple as they seem? Soc Sci Med 1996; 42: 617-24.

22. Redondo-Sendino A, Guallar-Castillon P, Benega JR, Artalezo FR. Gender differences in the utilization of health-care services among the older adults in Spain. BMC Public Health 2006; 6: 155-8.

23. Murray CJ, Lopez AD. The global burden of disease. Geneva, Switzerland: World Health Organization; 1996.

24. Wahab KW, Ojini FI, Sanya EO, Olokoba AB, Katibi IA, Omotoso AB. Correlation of admission blood pressure with 30 day outcome in acute ischemic stroke in Nigerians. Niger Med J 2007; 48: 58-61.

25. Joubert JD, Bradshaw D. Health of older persons. In: Ijumba P, Day C, Ntuli A eds. South African health review 2003/2004. Durban: Health systems.

26. Sahyoun NR, Lentzner H, Hoyert D, Robinson KN. Trends in causes of death among the elderly. Aging Trends; No 1: National center for Health Statistics, Hyattsville, Maryland 2001.

27. Levenson JW, Skerrett PJ, Gaziano JM. Reducing the global burden of cardiovascular disease: The role of risk factors. Prev Cardiol 2000; 4: 188-99.
28. Ajayi EA, Ajayi AO. Pattern and outcome of diabetic admissions at a federal medical center: A 5-year review. Ann Afr Med 2009; 8: 271-5.

29. Osuntokun BO, Bademosi O, Akinkugbe OO, Oyediran AB, Carlisle R. Incidence of stroke in an African city: results from stroke registry at Ibadan, Nigeria. 1973-1975. Stroke 1979; 10: 205-7.

30. Mandong BM, Madaki AJ. Mortality in a Nigerian teaching hospital: Experience at Jos University Teaching Hospital (JUTH) 1995-1999. Highland Med Res J 2002; 1: 16-18.

31. Adekunle O, Olatunde IO, Abdullateef RM. Causes and pattern of death in a tertiary health institution in South Western Nigeria. Niger Postgrad Med J 2008; 15: 247-50.

32. Petit PL, Van Ginneken JK. Analysis of hospital records in four African countries 1975-1990, with emphasis on infectious diseases. J Trop Hyg 1995; 98: 217-27

33. Arodiwe EB, Ulasi II, Ijoma CK. Left ventricular diastolic function in a predialysis patient population. West Afr J of Med 2010; 29: 225-9.

34. Ulasi II, Arodiwe EB, Ijoma CK. Left ventricular hypertrophy in African black patients with chronic renal failure at first evaluation. Ethn Dis 2006; 16: 859-64.

35. Naicker S. End stage renal disease in Sub-Saharan and South Africa. Kidney Int 2003; 63: S119-22.

36. Mabayoje MO, Bamgboye EL, Odutola TA, Mabadeje AFB. Chronic renal failure at the Lagos university teaching hospital: a 10-year review. Transplant Proc1992; 24: 1851-52.

37. Mcligeyo SO, Kayima JK. Evolution of Nephrology in East Africa in the last seventy years - studies and practice. East Afr Med J 1993; 70: 362 8

38. Barsoum RS, Rihan ZE, Ibrahim AS, Lebstein A. Long term intermittent haemodialysis in Egypt. Bull World Health Organ 1974; 51: 647-54.

39. Onwuchekwa AC, Asekomeh GE. Pattern of heart failure in a Nigerian teaching hospital. Vascular health and risk management 2009; 5: 745-50.

40. Smith SM, Mensah GA. Population, aging and implications for epidemic cardiovascular disease in Sub Saharan Africa. Ethn Dis 2003; 13: S77S80.

41. International Diabetes Foundation. Diabetes Atlas. 2009; http://www.diabetesatlas.org.map

42. Chuhwak EK, Puepet FH, Malu OA, Ohwovoriole AE. Morbidity and mortality study of diabetic admissions in Jos University Teaching Hospital. Diabetes 1999; 9: 76-7.

43. Olubuyide IO, Ayoola EA, Atoba MA. Hepatobiliary disease in Tropical Africa - the Ibadan experience. Trop Gastoenterol 1986; 7: 54-61.

44. Solanke TF, Olugbuyide IO. The causes of death in an elderly African population. J Trop Med Hyg 1990; 93: 270-4.

45. Ngom P, Clark S. Adult mortality in the era of HIV/AIDS: Sub-Saharan Africa. Paper at workshop on HIV/AIDS and Adult mortality in developing countries. Population division department of Economic and Social affairs, United Nations Secretariat, New York, 8-13. 2003.

46. Kolawole AO. Feasible cancer control strategies for Nigeria: mini-review. Am J of Trop Med and Publ health 2011; 1: 1-10. 